\title{
Digestive System Finding
}

National Cancer Institute

\section{Source}

National Cancer Institute. Digestive System Finding. NCI Thesaurus. Code C36279.

Symptoms, physical examination results, and/or laboratory test results related to the digestive system. 